Alfarama Journal of Basic \& Applied Sciences

Faculty of Science Port Said University https://ajbas.journals.ekb.eg

ajbas@sci.psu.edu.eg

http://sci.psu.edu.eg/en/

January 2021, Volume 2, Issue 1

DOI: $10.21608 /$ ajbas.2020.41969.1031

Submitted: 06-09-2020

Accepted: $06-10-2020$

Pages: 81-96

\title{
Antifungal Activity of Some Mediterranean Seaweed Against Macrophomina phaseolina and Fusarium Oxysporum in Vitro
}

\author{
Asmaa Lotfi ${ }^{1, *}$, Metwally Kottb ${ }^{2}$, Ahmed Elsayed $^{3}$ and Hesham Shafik ${ }^{4}$ \\ ${ }^{1}$ Botany Department, Faculty of Science, Port Said University, Port Said, Egypt \\ ${ }^{2}$ Botany Department, Faculty of Science, Suez Canal University, Ismailia, Egypt \\ ${ }^{3}$ Botany Department, Faculty of Science, Damietta University, Damietta, Egypt \\ ${ }^{4}$ Botany Department, Faculty of Science, Port Said University, Port Said, Egypt \\ * Corresponding author: asmaa.alallaf@sci.psu.edu.eg
}

\begin{abstract}
Seaweeds are naturally rich with biological active metabolites that could be promising to be used in the biological control. The present study was conducted to evaluate the antifungal potentiality of metabolites extracted from Ulva fasciata, Ulva lactuca and Cladophora sericea; against Macrophomina phaseolina (Tassi) Goid. and Fusarium oxysporum Schltdl. Four organic solvents hexane, chloroform, acetone and methanol were used for extraction of seaweeds metabolites to assay their biological efficiency on mycelium growth reduction of two candidate soil borne fungal pathogens on potato dextrose agar medium. The highest percentage of $F$. oxysporum and $M$. phaseolina growth reduction was observed by acetone extract of $U$. fasciata and methanol extract of C. sericea. The highest inhibition against $M$. phaseolina reached up to $28.97 \%$ by $U$. fasciata acetone extract and $24.77 \%$ by $C$. sericea methanol extract. The highest percentage of mycelial growth inhibition of $F$. oxysporum was observed by $U$. fasciata acetone extract $(23.58 \%)$ and $C$. sericea methanol extract (17.01\%). Analysis of acetone extract of $U$. fasciata by gas chromatography mass spectrophotometer GC/MS revealed the presence of some organic compounds with antifungal properties such as Phenol, 2,2'-methylenebis[6-(1,1-dimethylethyl)-4-methyl-, Di-n-octyl phthalate, 1,2-Benzenedicarboxylic acid, diisodecyl ester, Didecyl phthalate, Phthalic acid, bis (7-methyloctyl) ester, gamma Sitosterol, Cholest-5-en-3-ol, 24-propylidene-, (3. beta.) and Cyclononasiloxane, octadecamethyl-. The results suggest that the studied algal species can be used as potential bio-agent source in biological control of soil borne phytopathogenic fungi.
\end{abstract}

Keywords

Cladophora sericea, Fusarium oxysporum, Macrophomina phaseolina, Ulva fasciata, Ulva lactuca.

\section{INTRODUCTION}

Seaweeds produce a wide range of promising bioactive metabolites that have broad spectrum of biological activities such as antifungal, antibacterial and antioxidant activity. In recent years, there is an urgent need to explore novel natural products to overcome the problem of increasing the resistance of microorganisms [1]. Many researches are focused on crude extracts of seaweeds collected from Mediterranean seashores because of their potent antimicrobial action [2]. Bioactive secondary metabolites 
that produced by marine macroalgae are several like, Alkaloids, polyketides, cyclic peptide, polysaccharide, phlorotannins, diterpenoids, polyphenols, sterols, quinones, lipids and glycerols, most of them have antimicrobial activities [3]. Chemical composition differs between seaweeds according to species, maturity, habitats and environmental conditions [4].

Fusarium oxysporum and Macrophomina phaseolina are ubiquitous soil-borne pathogenic fungi that affect the root system of plants or the stem, in some cases developing on upper parts of the plant through transport or growth in the vessels, leading to vascular diseases. Such pathogens can cause economic loss because of plant yield loss [5]. Seaweeds extracts have antifungal activity against soil borne plant pathogenic fungi in addition it can stimulate plant growth [6]. Shobier et al., [7] reported that ethyl acetate and methanol extracts of $U$. lactuca collected from Alexandria Mediterranean coast showed high antifungal activities against Fusarium solani, Fusarium oxysporum, Tricoderma hamatum, Aspergillus flavipes and Candida albicans. Red alga like Gracilaria confervoides extracts reduced the radial growth of some pathogenic fungi such as Rhizoctonia solani and Fusarium solani [8]. Furthermore, Galal et al., [9] recorded positive antifungal activities of Codium fragile methanol extract against Alternaria alternate, Fusarium oxysporum, Alternaria brassicicola, Ulocladium botrytis and Botryotricum piluliferum.

This research aimed to: 1) assess the antifungal activity of three Mediterranean seaweeds taxa collected from Port Said governorate against two soil borne phytopathogenic fungi namely $M$. phaseolina and $F$. oxysporum under laboratory conditions and 2) detect bioactive compounds in algal crude extract by GC/MS analysis.

\section{MATERIALS AND METHODS}

\subsection{Seaweed collection and processing}

Seaweeds were harvested at morning during October and November 2017 from rocky substrate at the Mediterranean Egyptian coast at Port Said (31.276929 N, 32.2680327 E) (Fig. 1.).

Algal samples were hand-picked, washed with sea water to remove sand particles, invertebrate and epiphytes and were transported to the laboratory immediately in plastic bags half filled with sea water to avoid dryness. Samples were washed thoroughly with tap water and then with distilled water to remove adhering substances and salts and were dried under the shade at room temperature for 7 days. Air dried samples were ground with electric blender to a fine powder and transferred to labeled glass bottles for screening their antifungal activity [10]. The algal species were identified based on their morphology and anatomy using Seaweeds-a field manual [11], Seaweeds of India: the diversity and distribution of seaweeds of Gujarat coast [12] and A Field Guide to the British Seaweeds: As required for assistance in the classification of water bodies under the Water Framework Directive [13]. 


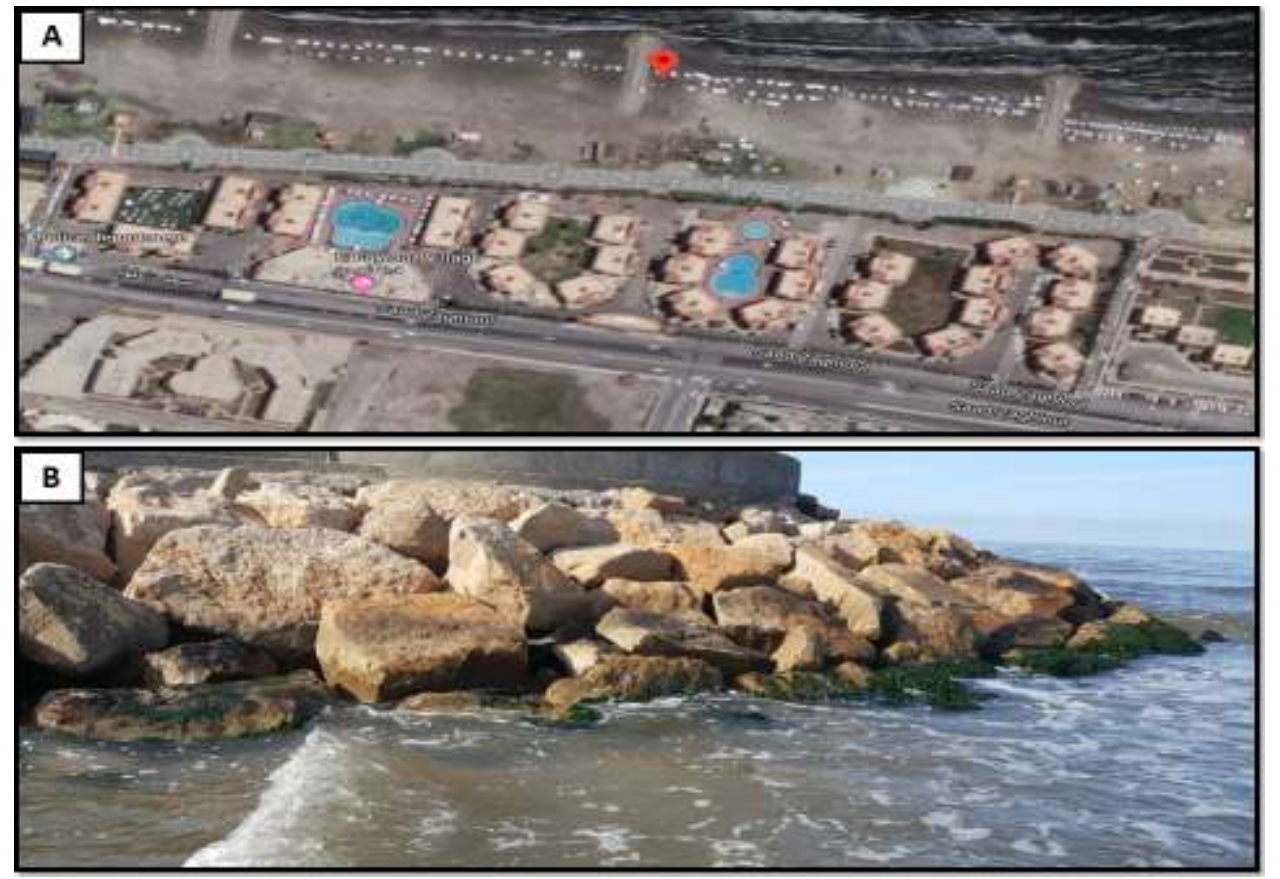

Fig. 1. (A) Map showing the collection site of seaweeds and (B) The area in where seaweeds were collected.

\subsection{Extract preparation for antifungal assay}

Two gram of each dried algal powder was successively extracted by maceration with continuous shaking for 24 hours using different organic solvents; hexane, chloroform, acetone and methanol $(1: 10 ; \mathrm{w} / \mathrm{v})$. The crude extract was obtained through evaporation of the organic solvent and then re-weighted. The percentage of each extract was determined as according to equation [14]:

$$
\text { Extract } \%=(\text { Weight of extract }(\mathrm{g}) / \text { Weight of sample (g) }) \text { 100 }
$$

The dried crude extracts were dissolved in dimethyl sulfoxide (DMSO), then sterilized by Millipore filtration method $(0.22 \mu \mathrm{m})[6]$ and stored in refrigerator for further use. The concentration of each extract was calculated according to the following equation (Concentration= weight of extract $(\mathrm{mg}) /$ volume of solvent (ml)) [15].

\subsection{Isolation of phytopathogenic fungi}

Fusarium isolation was prepared from collecting the tomato root naturally infested tissues. Small pieces $\left(c a . \leq 9 \mathrm{~mm}^{2}\right)$ from individual root samples were cut and placed on potato dextrose agar (PDA) medium in a Petri dish and incubated at $28^{\circ} \mathrm{C}$ in the dark for 7 days. The identification as $F$. oxysporum is based on morphological characteristics [16].

Potato tuber symptomatic plants were surface sterilized by $0.5 \% \mathrm{NaOCl}$ for $3 \mathrm{~min}$. Cross sections were made in tuber to observe the affected area. It was disinfected with70\% ethanol for $30 \mathrm{~s} .5 \mathrm{~mm}$ necrotic tissue were cultivated on (PDA) amended with $500 \mu \mathrm{L}-1 \mathrm{ml}$ chloramphenicol. Plates were incubated at $25^{\circ} \mathrm{C}$ for 6 days. Macrophomina identification was based on the growth characteristics, agar pigmentation and the presence of microsclerotia [17].

\subsection{Antifungal activity of algal extracts (in vitro assay)}

The antifungal activity of algal extracts against two phytopathogenic fungal candidates were assayed in vitro on PDA media; $200 \mathrm{~g}$ sliced potato, $20 \mathrm{~g}$ dextrose, $15 \mathrm{~g}$ agar and $1000 \mathrm{~mL}$ distilled water [18] and a well cut technique was adopted [19]. Two wells with $5 \mathrm{~mm}$ in diameter were punched in solid PDA medium and one was filled with $100 \mu \mathrm{l}$ of seaweeds extract and the other was filled with $100 \mu \mathrm{l}$ of DMSO and this is 
considered a negative control. Between the two wells fungal pathogen disk was inoculated. Positive control was performed by using two synthetic antifungals miconazole and nystatin.

Plates were incubated at $30^{\circ} \mathrm{C}$ and the percentage of fungal radial growth inhibition was recorded after three \& four days in case of $M$. phaseolina and till 6 days in case of $F$. oxysporum. Percentage of mycelia growth inhibition (MGI \%) was calculated using the following index [6]:

$$
\mathrm{MGI} \%=[(\text { Control }- \text { Test }) / \text { Control }] \times 100
$$

(Control $=$ fungus radial growth from the middle of fungal disc toward the negative control well, Test= fungus radial growth from the middle of fungal disc toward the extract well).

\subsection{Minimal inhibitory concentration (MIC) assay}

Seaweeds extracts were serially diluted by DMSO to obtain diluted concentrations in the range of 25, 50 and $75 \%$. Four wells were punched in PDA media. All wells were inoculated with $100 \mu \mathrm{l}$ of diluted extracts except the fourth well which was considered as negative control was inoculated with $100 \mu 1$ DMSO. The fungal disk was inoculated in the center. The MIC value was taken as the lowest concentration of extract which inhibit the growth of the tested phytopathogenic fungi [20].

\subsection{Analysis of $\boldsymbol{U}$. fasciata metabolic profiles by GC-MS}

$U$. fasciata acetone extract which showed the highest antifungal activity against $M$. phaseolina and $F$. oxysporum was analyzed using GC-MS.

Mass spectra were recorded using Shimadzu GCMS-QP2010 (Koyoto, Japan) equipped with Rtx-5MS fused bonded column ( $30 \mathrm{~m} \times 0.25 \mathrm{~mm}$ i.d. x $0.25 \mu \mathrm{m}$ film thickness) (Restek, USA) equipped with a splitsplitless injector. The initial column temperature was kept at $50^{\circ} \mathrm{C}$ for $3 \mathrm{~min}$ (isothermal) and programmed to $200^{\circ} \mathrm{C}$ at a rate of $15^{\circ} \mathrm{C} / \mathrm{min}$, and kept constant at $200^{\circ} \mathrm{C}$ for $5 \mathrm{~min}$ (isothermal). Then the Temperature was programmed to $240^{\circ} \mathrm{C}$ at a rate of $3^{\circ} \mathrm{C} / \mathrm{min}$, and kept constant at $240^{\circ} \mathrm{C}$ for $10 \mathrm{~min}$ (isothermal). Finally, the temperature was programmed to $300^{\circ} \mathrm{C}$ at a rate of $4{ }^{\circ} \mathrm{C} / \mathrm{min}$, and kept constant at $300^{\circ} \mathrm{C}$ for 10 $\min$ (isothermal). Injector temperature was $280^{\circ} \mathrm{C}$. Helium carrier gas flow rate was $1.41 \mathrm{ml} / \mathrm{min}$. All the mass spectra were recorded applying the following condition: (equipment current) filament emission current, $60 \mathrm{~mA}$; ionization voltage, $70 \mathrm{eV}$; ion source, $220^{\circ} \mathrm{C}$. Diluted samples $(1 \% \mathrm{v} / \mathrm{v})$ were injected with split mode (split ratio 1: 15).

\subsection{Statistical analysis}

The results were expressed as mean of three replicates \pm standard error. Data was statistically analyzed by using analysis of variance (ANOVA) at $\mathrm{P}<0.05$ and means were separated using the least significant difference (LSD). Statistical analysis was done with IBM SPSS Statistics version 25 [21].

\section{RESULTS AND DISCUSSION}

\subsection{Identification of the collected seaweeds}

Seaweeds collected from the Mediterranean seashores at Port said were identified as (A) Ulva lactuca L, (B) Ulva fasciata Delile and (C) Cladophora sericea (Hudson) Kützing as shown in Fig. 2.

\subsection{Percentage of Crude extract of seaweeds according to different organic solvents}

Organic solvent used in extraction process has a significant effect on extract concentration as shown in Fig. 3. The total crude extract was about 8.73, 12.87 and 15.605 in case of $U$. fasciata, U. lactuca and $C$. sericea respectively as shown in fig. 3. Methanol maintained the highest percentage of extract in all algal species and that similar to Abdel-Aal et al. [14] who use five organic solvents to extract metabolites of Spirogyra longata. 


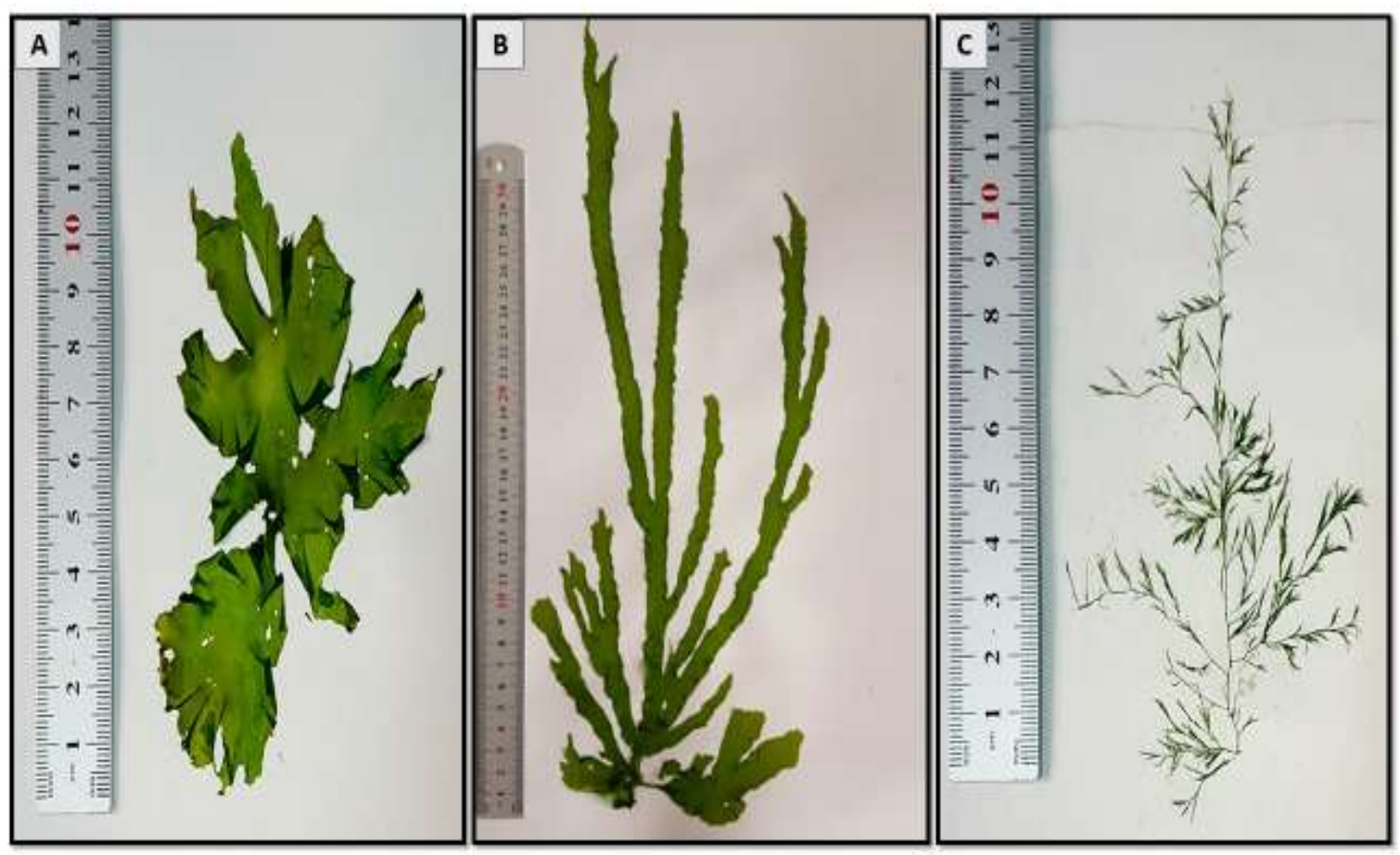

Fig. 2. Morphological features of the collected marine algal species; A. U. lactuca, B. $U$. fasciata and C. C. sericea.

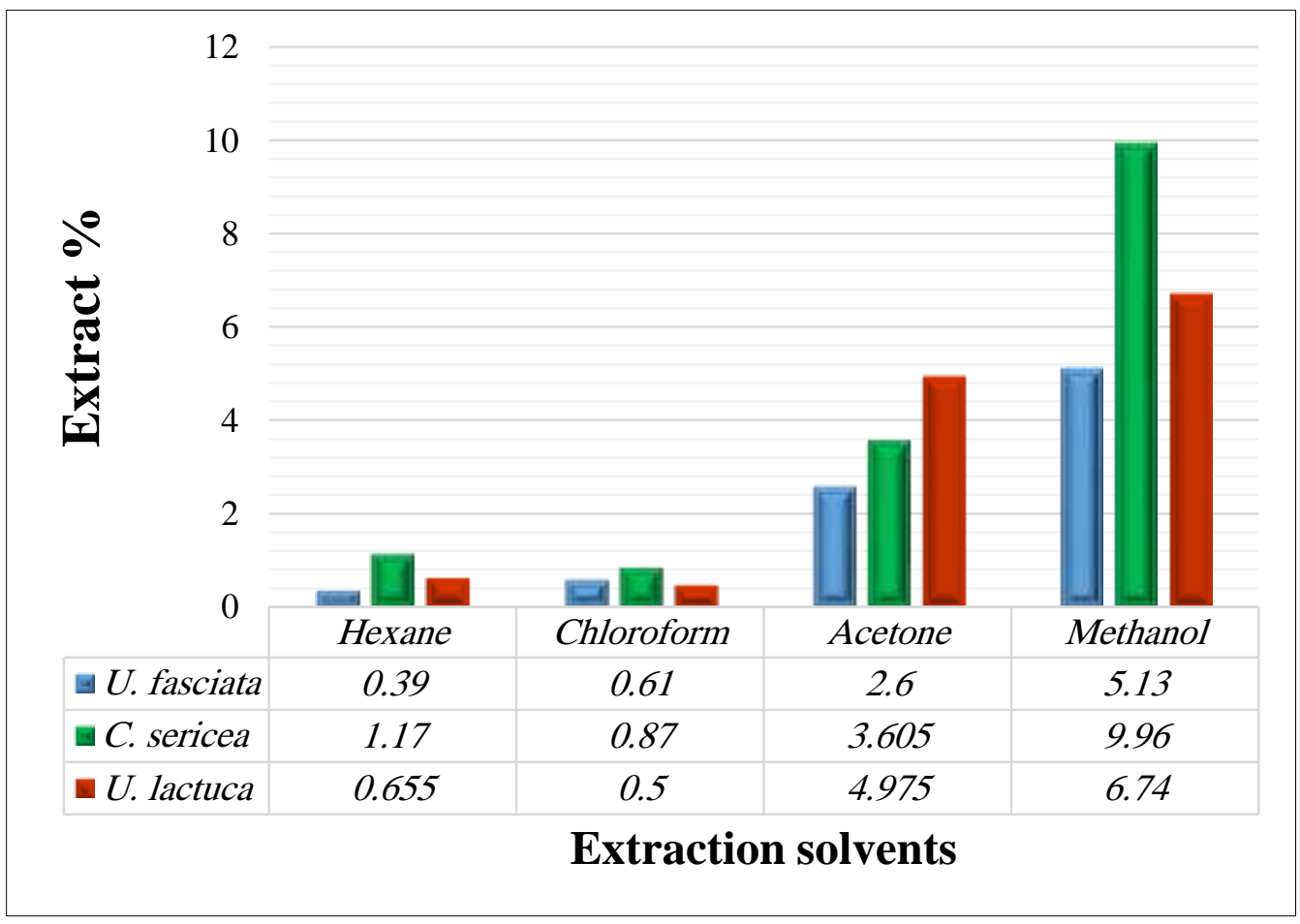

Fig. 3. Percentage of crude extracts from $U$. fasciata, $C$. sericea and $U$. lactuca by four organic solvents. 


\subsection{Antifungal activity of seaweeds extracts against $M$. phaseolina and $F$. oxysporum (in vitro assay)}

Data of tables 1 and 2 showed that both of phytopathogenic fungal candidates were inhibited by $U$. fasciata acetone extract and the highest inhibitory effect recorded against $M$. phaseolina reached up to $28.98 \%$. In table 2, there is no significant difference between miconazole and acetone extract of $U$. fasciata in their inhibitory action against $M$. phaseolina. The inhibitory effect of $U$. fasciata acetone extract (24.78 $\mathrm{mg} / \mathrm{ml})$ against $F$. oxysporum and both of $U$. lactuca hexane extract $(6.5 \mathrm{mg} / \mathrm{ml})$ and $C$. sericea methanol extract $(49.8 \mathrm{mg} / \mathrm{ml})$ against $M$. phaseolina was higher than miconazole and nystatin. Similar finding was matching with El-Sheekh \& Soliman [22] who found that $U$. fasciata was effective bioagent in inhibiting the mycelial radial growth of $F$. solani and Rhizoctonia solani on PDA medium in comparing with control.

$U$. lactuca methanol extract was not effective in mycelium growth inhibition of $F$. oxysporum and $M$. phaseolina as shown in table 3 and 4 and these results disagree with Zouaoui \& Ghalem [23] who reported that methanol extract obtained from $U$. lactuca showed antifungal activity for Candida albicans. There is no significant difference in the inhibitory effect between positive control miconazole and $U$. lactuca hexane extract at $4.91 \mathrm{mg} / \mathrm{ml}$ concentration.

C. sericea methanol extract at $49.8 \mathrm{mg} / \mathrm{ml}$ and $U$. fasciata acetone extract at $24.78 \mathrm{mg} / \mathrm{ml}$ have a role in inhibiting the growth of M. phaseolina as shown in table 2 and 6. The results are not matching with ElSheekh \& Soliman [22] and Soliman et al. [8] who reported that there is no linear growth reduction of $M$. phaseolina by extracts of Gracilaria confervoides, U. fasciata and Enteromorpha flexuosa.

$C$. sericea hexane, chloroform and acetone extracts show non-significant results in both $F$. oxysporum and $M$. phaseolina as shown in table 5. F. oxysporum mycelium growth was inhibited by $C$. sericea methanol extract $(17.01 \%)$. Methanol extract of $C$. sericea was found high effective against $F$. oxysporum and $M$. phaseolina and methanol extract of other seaweeds was not effective against any pathogens. Khan $e t$ al. [24] reported that most of the seaweeds inhibited growth of $F$. oxypsorum, M. phaseolina and $R$. solani. The highest antifungal activities were observed in both aqueous and methanol extracts and this matching with our data.

Obtained data revealed that acetone was the most effective extraction solvent with significant antifungal activity followed by methanol and this finding is contrasted to Al-Saif et al. [25] who found that chloroform was the most effective solvent.

M. phaseolina was more sensitive and showed higher radial growth reduction by seaweed extracts than F. oxysporum. The results are in agreement with the results of Galal et al.[9] who proved that $F$. oxysporum was less affected to algal extract.

The difference in this study results and other studies could attributed to difference in tested pathogenic fungi, type of algal species, extraction solvent and extraction method. The difference in chemical composition of seaweeds differs according to seaweeds species, habitats and environmental conditions.

\subsection{Minimal inhibitory concentration (MIC) assay}

Most of seaweeds extracts inhibit the growth of M. phaseolina and $F$. oxysporum at concentration of the crude extract. $U$. lactuca hexane extract inhibit the growth of $M$. phaseolina at concentrations of $6.55 \mathrm{mg} / \mathrm{ml}$ and $4.91 \mathrm{mg} / \mathrm{ml}$ and both concentrations were not effective against $F$. oxysporum as shown in table 3 . In table 5, mycelium reduction of $M$. phaseolina and $F$. oxysporum was by methanol extract of $C$. sericea at $49.8 \mathrm{mg} / \mathrm{ml}$ only. Recorded results was not matched with Ibraheem et al., [26] who found that methnol extract of Sargassum latifolium and Padina gymnospora was effective in mycelium reduction of Fusarium solani and Rhizoctonium solani at all concentrations.

Inhibitory effect of different concentration of $F$. oxysporum by methanol extract of $C$. sericea was clear in Fig.4 (I), While Fig.5 showed M. phaseolina mycelium inhibition at $24.7 \mathrm{mg} / \mathrm{ml}$ concentration by $C$. sericea 
methanol extract and $U$. fasciata acetone extract. Fig 6. clarifies that M. phaseolina growth inhibited at 4.91 $\mathrm{mg} / \mathrm{ml}(75 \%)$ and other lower concentrations were not effective in growth inhibition.

Table 1. Determination of MIC for different extraction solvents of $U$. fasciata against $F$. oxysporum and M. phaseolina

\begin{tabular}{rccccc}
\hline \multirow{3}{*}{ Hexane } & Concentration $(\mathrm{mg} / \mathrm{ml})$ & $\mathbf{1 . 3}$ & $\mathbf{2 . 6}$ & $\mathbf{3 . 9}$ & $\mathbf{5 . 2}$ \\
\cline { 2 - 6 } & F. oxysporum & - & - & - & - \\
\cline { 2 - 6 } & M. phaseolina & - & - & - & - \\
\hline \multirow{3}{*}{ Chloroform } & Concentration $(\mathrm{mg} / \mathrm{ml})$ & $\mathbf{1 . 5 2}$ & $\mathbf{3 . 0 5}$ & $\mathbf{4 . 5 7}$ & $\mathbf{6 . 1}$ \\
\cline { 2 - 6 } & F. oxysporum & - & - & - & - \\
\cline { 2 - 6 } Acetone & M. phaseolina & - & - & - & - \\
\cline { 2 - 6 } & Concentration $(\mathrm{mg} / \mathrm{ml})$ & $\mathbf{6 . 1 9}$ & $\mathbf{1 2 . 3 9}$ & $\mathbf{1 8 . 5 8}$ & $\mathbf{2 4 . 7 8}$ \\
\cline { 2 - 6 } & F. oxysporum & - & - & - & + \\
\hline \multirow{3}{*}{ Methanol } & M. phaseolina & - & - & - & + \\
\cline { 2 - 6 } & Concentration $(\mathrm{mg} / \mathrm{ml})$ & $\mathbf{8 . 4 1}$ & $\mathbf{1 6 . 8 3}$ & $\mathbf{2 5 . 2 5}$ & $\mathbf{3 3 . 6 7}$ \\
\cline { 2 - 6 } & F. oxysporum & - & - & - & - \\
\cline { 2 - 6 } & M. phaseolina & - & - & - & -
\end{tabular}

$(+)$ means there is an antifungal activity to extract and (-) means there is no antifungal activity was detected to extract

Table 2. MGI \% of phytopathogenic fungal candidates by different extraction solvents of $U$. fasciata resulting from MIC

\begin{tabular}{|c|c|c|c|}
\hline Treatments & Conc & $\begin{array}{c}\text { F. oxysporum } \\
\text { MGI \% }\end{array}$ & $\begin{array}{c}\text { M. phaseolina } \\
\text { MGI \% }\end{array}$ \\
\hline Miconazole & $0.03 \mathrm{mg} / \mathrm{ml}$ & $24 \pm 1.76^{a}$ & $10.76 \pm 2.98^{\mathrm{e}}$ \\
\hline Nystatin & $0.03 \mathrm{mg} / \mathrm{ml}$ & $12.2 \pm 2.32^{\mathrm{c}}$ & $14.86 \pm 0.63^{f}$ \\
\hline Hexane & $5.2 \mathrm{mg} / \mathrm{ml}$ & $0^{\mathrm{b}}$ & $0^{d}$ \\
\hline Chloroform & $6.1 \mathrm{mg} / \mathrm{ml}$ & $0^{b}$ & $0^{d}$ \\
\hline Acetone & $24.78 \mathrm{mg} / \mathrm{ml}$ & $23.58 \pm 0.25^{a}$ & $28.98 \pm 0.74^{g}$ \\
\hline Methanol & $33.67 \mathrm{mg} / \mathrm{ml}$ & $0^{\mathrm{b}}$ & $0^{d}$ \\
\hline \multicolumn{2}{|c|}{ LSD at $p \leq 0.05$} & 3.69 & 3.95 \\
\hline
\end{tabular}

All values are mean $(n=3) \pm$ standard error.

Values with the same letters in the same column are not significantly different at $p \leq 0.05$ 
Table 3. Determination of MIC for different extraction solvents of $U$. lactuca against $F$. oxysporum and M. phaseolina

\begin{tabular}{|c|c|c|c|c|c|}
\hline \multirow{3}{*}{ Hexane } & Concentration $(\mathrm{mg} / \mathrm{ml})$ & 1.63 & 3.27 & 4.91 & 6.55 \\
\hline & F. oxysporum & - & - & - & - \\
\hline & M. phaseolina & - & - & + & + \\
\hline \multirow{3}{*}{ Chloroform } & Concentration $(\mathrm{mg} / \mathrm{ml})$ & 1 & 2 & 3 & 4 \\
\hline & F. oxysporum & - & - & - & - \\
\hline & M. phaseolina & - & - & - & - \\
\hline \multirow{3}{*}{ Acetone } & Concentration $(\mathrm{mg} / \mathrm{ml})$ & 6.21 & 12.43 & 18.65 & 24.87 \\
\hline & F. oxysporum & - & - & - & - \\
\hline & M. phaseolina & - & - & - & - \\
\hline \multirow{3}{*}{ Methanol } & Concentration $(\mathrm{mg} / \mathrm{ml})$ & 6.12 & 12.24 & 18.36 & 24.48 \\
\hline & F. oxysporum & - & - & - & - \\
\hline & M. phaseolina & - & - & - & - \\
\hline
\end{tabular}

$(+)$ means there is an antifungal activity to extract and (-) means there is no antifungal activity was detected to extract

Table 4. MGI \% of phytopathogenic fungal candidates by different extraction solvents of $\boldsymbol{U}$. lactuca resulting from $\mathrm{MIC}$

\begin{tabular}{|c|c|c|c|}
\hline Treatments & Conc & $\begin{array}{c}\text { F. oxysporum } \\
\text { MGI \% }\end{array}$ & $\begin{array}{c}\text { M. phaseolina } \\
\text { MGI \% }\end{array}$ \\
\hline Miconazole & $0.03 \mathrm{mg} / \mathrm{ml}$ & $24 \pm 1.76^{a}$ & $10.76 \pm 2.98^{\mathrm{e}}$ \\
\hline Nystatin & $0.03 \mathrm{mg} / \mathrm{ml}$ & $12.2 \pm 2.32^{b}$ & $14.86 \pm 0.63^{f}$ \\
\hline Hexane & $6.5 \mathrm{mg} / \mathrm{ml}$ & $0^{\mathrm{c}}$ & $22.97 \pm 0.98^{g}$ \\
\hline Hexane & $4.91 \mathrm{mg} / \mathrm{ml}$ & $0^{c}$ & $10.46 \pm 0.12^{e}$ \\
\hline Chloroform & $4 \mathrm{mg} / \mathrm{ml}$ & $0^{\mathrm{c}}$ & $0^{d}$ \\
\hline Acetone & $24.8 \mathrm{mg} / \mathrm{ml}$ & $0^{\mathrm{c}}$ & $0^{\mathrm{d}}$ \\
\hline Methanol & $24.4 \mathrm{mg} / \mathrm{ml}$ & $0^{\mathrm{c}}$ & $0^{d}$ \\
\hline \multicolumn{2}{|c|}{ LSD at $p \leq 0.05$} & 3.35 & 3.68 \\
\hline
\end{tabular}

All values are mean $(\mathrm{n}=3) \pm$ standard error.

Values with the same letters in the same column are not significantly different at $p \leq 0.05$ 
Table 5. Determination of MIC for different extraction solvents of $C$. sericea against $F$. oxysporum and M. phaseolina

\begin{tabular}{|c|c|c|c|c|c|}
\hline \multirow{3}{*}{ Hexane } & Concentration $(\mathrm{mg} / \mathrm{ml})$ & 4.87 & 9.75 & 14.62 & 19.5 \\
\hline & F. oxysporum & - & - & - & - \\
\hline & M. phaseolina & - & - & - & - \\
\hline \multirow{3}{*}{ Chloroform } & Concentration $(\mathrm{mg} / \mathrm{ml})$ & 1.45 & 2.9 & 4.35 & 5.8 \\
\hline & F. oxysporum & - & - & - & - \\
\hline & M. phaseolina & - & - & - & - \\
\hline \multirow{3}{*}{ Acetone } & Concentration $(\mathrm{mg} / \mathrm{ml})$ & 5.63 & 11.26 & 16.89 & 22.53 \\
\hline & F. oxysporum & - & - & - & - \\
\hline & M. phaseolina & - & - & - & - \\
\hline \multirow{3}{*}{ Methanol } & Concentration $(\mathrm{mg} / \mathrm{ml})$ & 12.45 & 24.9 & 37.35 & 49.8 \\
\hline & F. oxysporum & - & - & - & + \\
\hline & M. phaseolina & - & - & - & + \\
\hline
\end{tabular}

$(+)$ means there is an antifungal activity to extract and (-) means there is no antifungal activity was detected to extract

Table 6. MGI \% of phytopathogenic fungal candidates by different extraction solvents of $C$. sericea resulting from $\mathrm{MIC}$

\begin{tabular}{|c|c|c|c|}
\hline Treatments & Conc & $\begin{array}{c}\text { F. oxysporum } \\
\text { MGI \% }\end{array}$ & $\begin{array}{c}\text { M. phaseolina } \\
\text { MGI \% }\end{array}$ \\
\hline Miconazole & $0.03 \mathrm{mg} / \mathrm{ml}$ & $24 \pm 1.76^{a}$ & $10.76 \pm 2.98^{f}$ \\
\hline Nystatin & $0.03 \mathrm{mg} / \mathrm{ml}$ & $12.2 \pm 2.32^{b}$ & $14.86 \pm 0.63^{g}$ \\
\hline Hexane & $19.5 \mathrm{mg} / \mathrm{ml}$ & $0^{\mathrm{c}}$ & $0^{\mathrm{e}}$ \\
\hline Chloroform & $5.8 \mathrm{mg} / \mathrm{ml}$ & $0^{\mathrm{c}}$ & $0^{\mathrm{e}}$ \\
\hline Acetone & $22.5 \mathrm{mg} / \mathrm{ml}$ & $0^{\mathrm{c}}$ & $0^{\mathrm{e}}$ \\
\hline Methanol & $49.8 \mathrm{mg} / \mathrm{ml}$ & $17.01 \pm 0.17^{d}$ & $24.77 \pm 0.79^{h}$ \\
\hline \multicolumn{2}{|c|}{ LSD at $p \leq 0.05$} & 3.68 & 3.97 \\
\hline
\end{tabular}

All values are mean $(n=3) \pm$ standard error.

Values with the same letters in the same column are not significantly different at $p \leq 0.05$ 

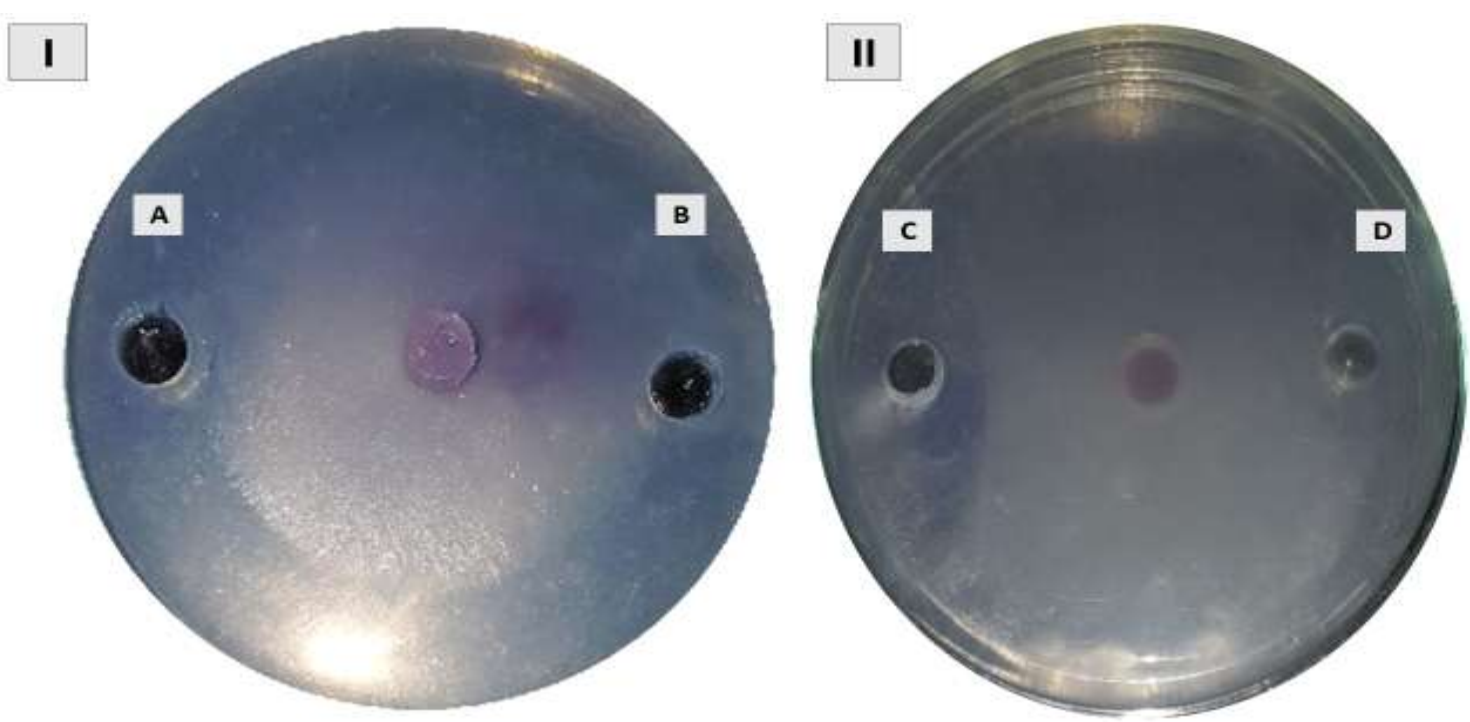

Fig.4. (I) Mycelial growth inhibition of $F$. oxysporum by methanol extract of $C$. sericea; A. represents methanol extract $C$. sericea dissolved in DMSO and B. represents DMSO only. (II) Effect of miconazole (positive control) on F. oxysporum growth; C. refers to miconazole that is dissolved in water and D. refers to water.
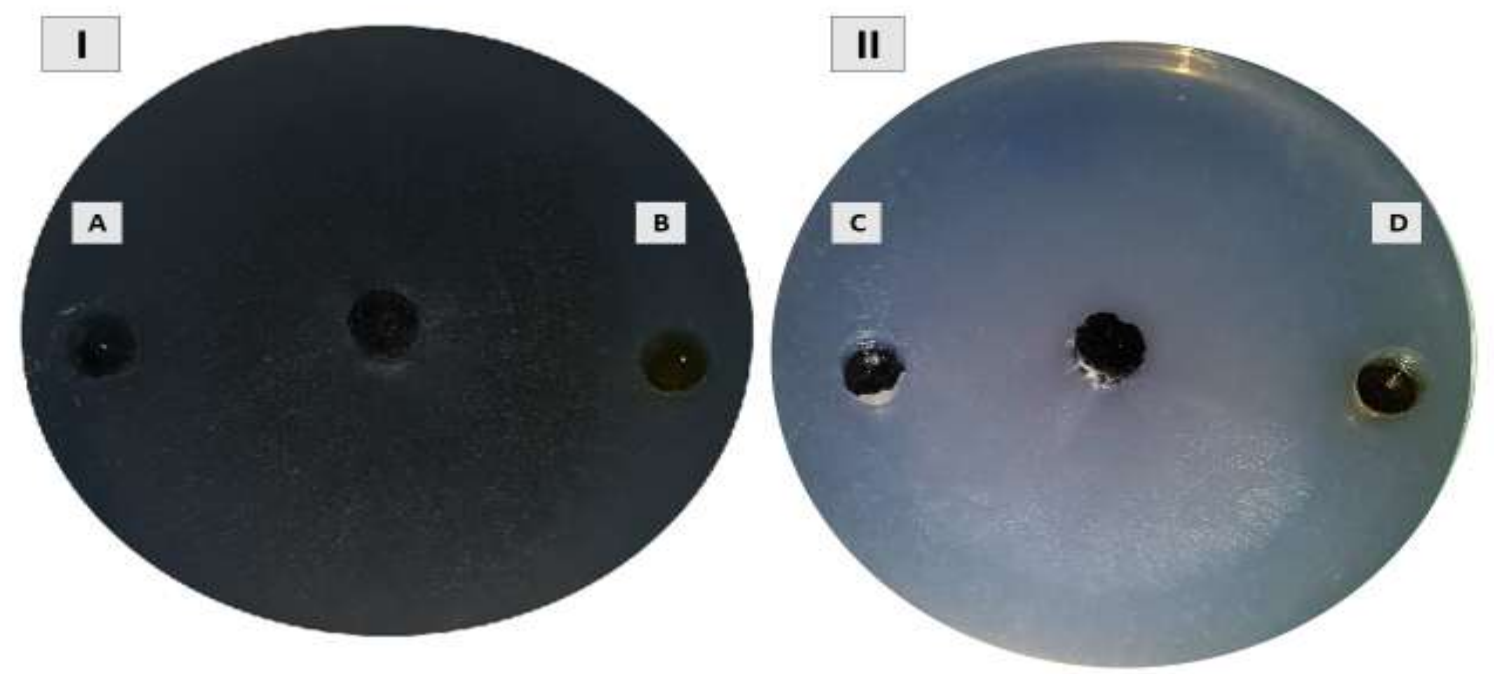

Fig. 5. (I) Mycelial growth inhibition of $M$. phaseolina by $C$. sericea methanol extract; A. refers to DMSO only and B. refers to $C$. sericea methanol extract dissolved in DMSO. (II) Growth inhibition of $M$. phaseolina by $U$. fasciata acetone extract; C. refers to DMSO only and $\mathrm{D}$. refers to by $U$. fasciata acetone extract. 


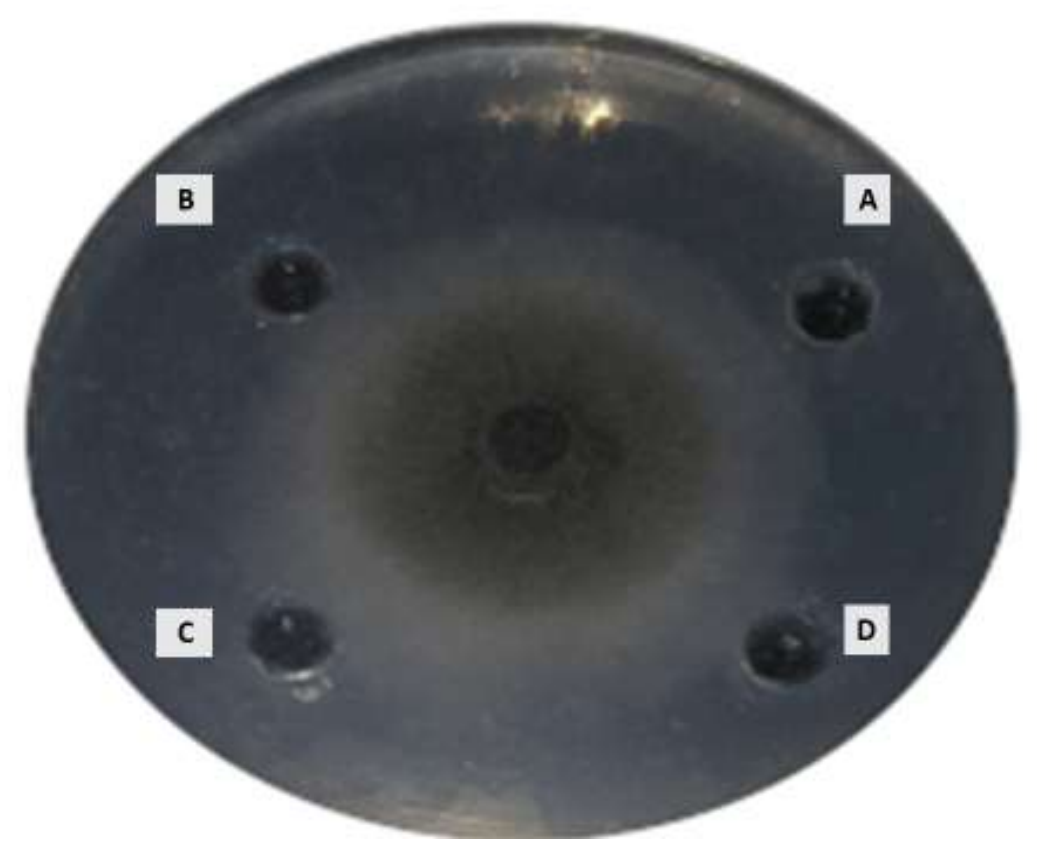

Fig. 6. MIC of $U$. lactuca hexane extract; A. represents $75 \%$ concentration of extract (4.91 $\mathrm{mg} / \mathrm{ml}$ ) and this concentration inhibit $M$. phaseolina growth, B. represents $50 \%$ concentration of extract $(3.27 \mathrm{mg} / \mathrm{ml})$, C. represents $25 \%$ concentration of extract $(1.63 \mathrm{mg} / \mathrm{ml})$ and $\mathrm{D}$. represents DMSO only. B, C and D show that there is no effect of DMSO and extract at these concentrations (50 and 25\%) on M. phaseolina growth.

\subsection{Analysis of $\boldsymbol{U}$. fasciata metabolic profiles by GC-MS}

Results of table 7 revealed that eleven bioactive compounds were detected in $U$. fasciata acetone fraction using GC/MS. The most abundant compounds are gamma Sitosterol, Didecyl phthalate, 1,2Benzenedicarboxylic acid, diisodecyl ester, Cyclononasiloxane, octadecamethyl- and Phenol, 2,2'methylenebis [6-(1,1-dimethylethyl)-4-methyl-. Compounds result from GC/MS analysis may be the reason of M. phaseolina and F. oxysporum growth inhibition by $U$. fasciata acetone extract.

Seaweeds can be considered as a diverse source of bioactive metabolites due to harsh environmental conditions in which they exist. Macroalgae metabolites act as effective control measures and possess antifungal, antibacterial, antiviral and other biological activities [27]. Phenol, 2,2'-methylenebis[6-(1,1dimethylethyl)-4-methyl- that is detected by GC-MS is one of the powerful compound with antifungal, antibacterial, antiseptic, antioxidant and germicidal properties due to its toxic potential [28]. It was reported that gamma-sitosterol has antimicrobial and antiviral activity [29]. It was proven that plants or algae such as Lythrum sp. and Sargassum sp. that usually grow in water flow can synthesize phthalates that are known of their antimicrobial activity [30].

Results suggest that the antifungal activity of $U$. fasciata acetone extract may be due to the activity of only one compound or through a synergetic effect between all identified powerful bioactive compounds with antifungal action. 


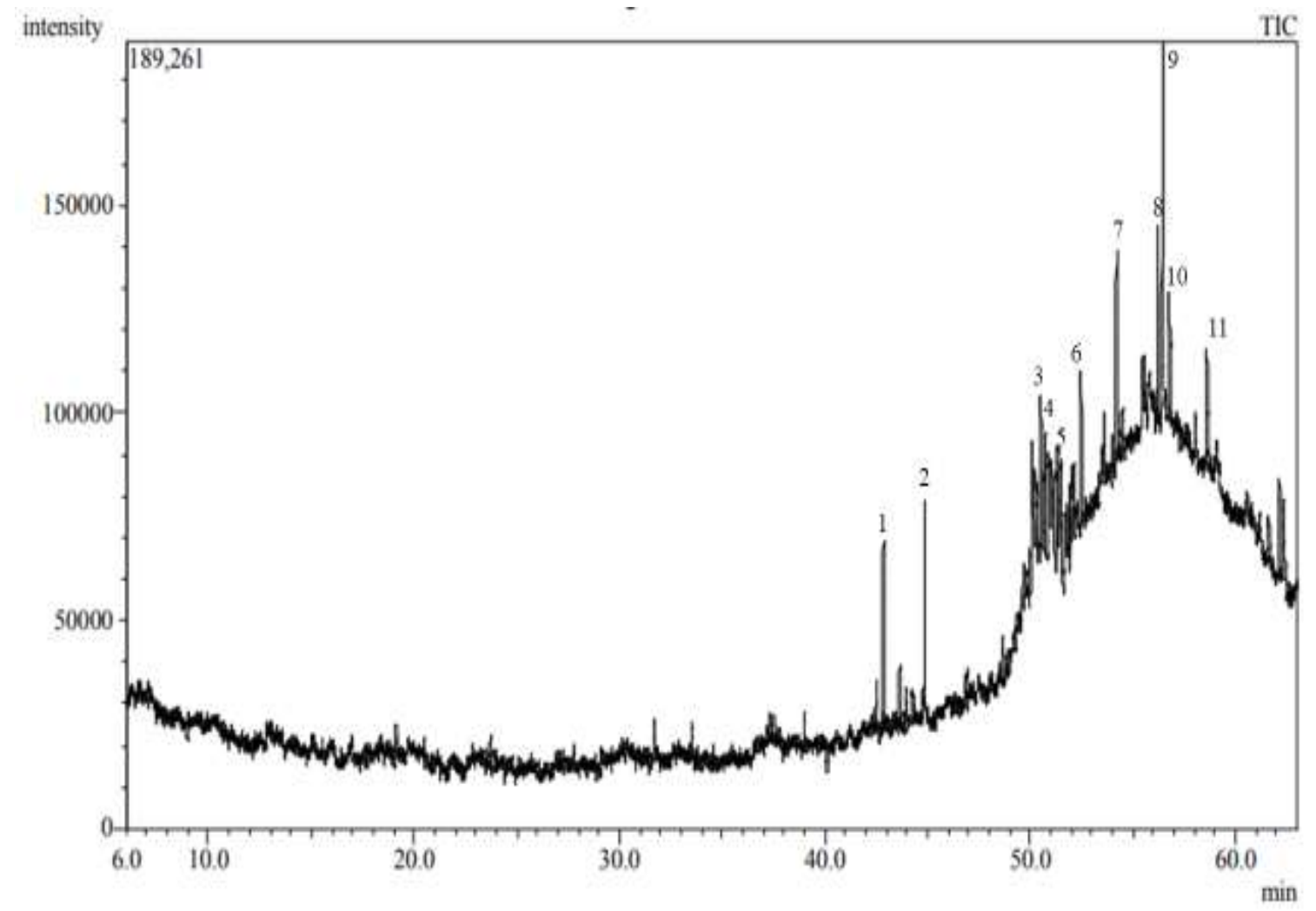

Fig. 7. Total ion chromatogram of GC-MS of $U$. fasciata acetone extract. 
Table 7. GC/MS analysis of bioactive volatile compounds of $\boldsymbol{U}$. fasciata acetone extract

\begin{tabular}{|c|c|c|c|c|c|c|}
\hline No. & $\mathbf{R}_{\mathbf{t}}$ & Compound name & $\begin{array}{c}\text { Molecular } \\
\text { formula }\end{array}$ & $\begin{array}{c}\text { Molecular } \\
\text { weight }\end{array}$ & $\begin{array}{c}\text { Base } \\
\text { peak } \\
\mathbf{m} / \mathbf{z}\end{array}$ & $\begin{array}{c}\text { Area } \\
\%\end{array}$ \\
\hline 1 & 42.852 & $\begin{array}{c}\text { Phenol, 2,2'- } \\
\text { methylenebis[6-(1,1- } \\
\text { dimethylethyl)-4- } \\
\text { methyl- } \\
\text { (Isomer 1) }\end{array}$ & $\mathrm{C}_{23} \mathrm{H}_{32} \mathrm{O}_{2}$ & 340 & 177.10 & 7.08 \\
\hline 2 & 44.841 & Di-n-octyl phthalate & $\mathrm{C}_{24} \mathrm{H}_{38} \mathrm{O}_{4}$ & 390 & 149.05 & 7.03 \\
\hline 3 & 50.506 & $\begin{array}{c}1,2- \\
\text { Benzenedicarboxylic } \\
\text { acid, diisodecyl ester }\end{array}$ & $\mathrm{C}_{28} \mathrm{H}_{46} \mathrm{O}_{4}$ & 446 & 149 & 8.93 \\
\hline 4 & 50.720 & Didecyl phthalate & $\mathrm{C}_{28} \mathrm{H}_{46} \mathrm{O}_{4}$ & 446 & 148.95 & 10.08 \\
\hline 5 & 51.328 & $\begin{array}{l}\text { Phthalic acid, bis(7- } \\
\text { methyloctyl) ester }\end{array}$ & $\mathrm{C}_{26} \mathrm{H}_{42} \mathrm{O}_{4}$ & 418 & 149 & 6.14 \\
\hline 6 & 52.475 & $\begin{array}{c}\text { Phenol, 2,2'- } \\
\text { methylenebis[6-(1,1- } \\
\text { dimethylethyl)-4- } \\
\text { methyl- (Isomer 2) }\end{array}$ & $\mathrm{C}_{23} \mathrm{H}_{32} \mathrm{O}_{2}$ & 340 & 177.10 & 4.45 \\
\hline 7 & 54.196 & $\begin{array}{c}\text { Phenol, 2,2'- } \\
\text { methylenebis[6-(1,1- } \\
\text { dimethylethyl)-4- } \\
\text { methyl- (Isomer 3) }\end{array}$ & $\mathrm{C}_{23} \mathrm{H}_{32} \mathrm{O}_{2}$ & 340 & 177.10 & 7.45 \\
\hline 8 & 56.192 & $\begin{array}{c}\text { Phenol, 2,2'- } \\
\text { methylenebis[6-(1,1- } \\
\text { dimethylethyl)-4- } \\
\text { methyl- (Isomer 4) }\end{array}$ & $\mathrm{C}_{23} \mathrm{H}_{32} \mathrm{O}_{2}$ & 340 & 177.10 & 8.10 \\
\hline 9 & 56.429 & .gamma.-Sitosterol & $\mathrm{C}_{29} \mathrm{H}_{50} \mathrm{O}$ & 414 & 43.05 & 21.77 \\
\hline 10 & 56.764 & $\begin{array}{l}\text { Cholest-5-en-3-ol, 24- } \\
\text { propylidene-, } \\
\text { (3.beta.)- }\end{array}$ & $\mathrm{C}_{30} \mathrm{H}_{50} \mathrm{O}$ & 426 & 55.05 & 6.32 \\
\hline 11 & 58.596 & $\begin{array}{c}\text { Cyclononasiloxane, } \\
\text { octadecamethyl- }\end{array}$ & $\mathrm{C}_{18} \mathrm{H}_{54} \mathrm{O}_{9} \mathrm{Si}_{9}$ & 666 & 73.05 & 8.17 \\
\hline \multicolumn{6}{|c|}{ Total identified } & 95.52 \\
\hline
\end{tabular}




\section{CONCULSION}

The results of the present study revealed that $U$. fasciata acetone extract was the most effective extract in mycelial growth reduction of M. phaseolina and $F$. oxysporum. It confirmed by GC-MS analysis that several bioactive compounds were recorded in $U$. fasciata acetone extract like Phenol, 2,2'-methylenebis[6-(1,1dimethylethyl)-4-methyl- and gamma-sitosterol. Thus, this potent extract has a promising future scope to be used as biocontrol measure against diseases caused by soil borne phytopathogenic fungi; as eco-friendly, natural and cheap fungicide.

\section{REFERENCES}

[1] BelatTMAniA, Z. ET AL. Potential uses of the brown seaweed Cystoseira humilis biomass: 2Fatty acid composition, antioxidant and antibacterial activities. J. Mater. Environ. Sci 7, 2074-2081 (2016).

[2] ABDEL-KHALIQ, A., HASSAN, H. M., RATEB, M. E. \& HAMMOUDA, O. Antimicrobial activity of three Ulva species collected from some Egyptian Mediterranean seashores. Int. J. Eng. Res. Gen. Sci. 2, 648-669 (2014).

[3] CABRITA, M. T., VALE, C. \& RAUTER, A. P. Halogenated compounds from marine algae. Mar. Drugs 8, 2301-2317 (2010).

[4] ITO, K. \& HORI, K. SEAWEED: chemical composition and potential food uses. Food Rev. Int. 5, 101-144 (1989).

[5] LUCAS, P. Diseases caused by soil-borne pathogens. in The epidemiology of plant diseases 373386 (Springer, 2006).

[6] DE CORATO, U., SAlimbEni, R., DE PRETIS, A., AVELlA, N. \& PATRUNO, G. Antifungal activity of crude extracts from brown and red seaweeds by a supercritical carbon dioxide technique against fruit postharvest fungal diseases. Postharvest Biol. Technol. 131, 16-30 (2017).

[7] SHOBIER, A. H., GHANI, S. A. A. \& BARAKAT, K. M. GC/MS spectroscopic approach and antifungal potential of bioactive extracts produced by marine macroalgae. Egypt. J. Aquat. Res. 42 , 289-299 (2016).

[8] SOLIMAN, A. S., AHMED, A. Y., ABDEL-GHAFOUR, S. E., EL-SHEEKH, M. M. \& SOBHY, H. M. Antifungal bio-efficacy of the red algae Gracilaria confervoides extracts against three pathogenic fungi of cucumber plant. Middle East J Appl Sci 8, 727-735 (2018).

[9] GALAL, H. R. M., SALEM, W. M. \& NASR EL-DEEN, F. Biological control of some pathogenic fungi using marine algae. Res J Microbiol 6, 645-657 (2011).

[10] KHAIRY, H. M. \& EL-SHEIKH, M. A. Antioxidant activity and mineral composition of three Mediterranean common seaweeds from Abu-Qir Bay, Egypt. Saudi J. Biol. Sci. 22, 623-630 (2015).

[11] DHARGALKAR, V. K. \& KAVLEKAR, D. P. Seaweeds-a field manual. (2004).

[12] JHA, B., REDDY, C. R. K., THAKUR, M. C. \& RAO, M. U. Seaweeds of India: the diversity and distribution of seaweeds of Gujarat coast. vol. 3 (Springer Science \& Business Media, 2009). 
[13] WELLS, E. A FIELD GUIDE TO THE BRITISH SEAWEEDS: As required for assistance in the classification of water bodies under the Water Framework Directive. Wells Mar. Surv. Br.

[14] ABDEL-AAL, E. I., HAROON, A. M. \& MOFEED, J. Successive solvent extraction and GC-MS analysis for the evaluation of the phytochemical constituents of the filamentous green alga Spirogyra longata. Egypt. J. Aquat. Res. 41, 233-246 (2015).

[15] MOUBAYED, N. M. S., AL HOURI, H. J., AL KHUlAIFI, M. M. \& AL FARRAJ, D. A. Antimicrobial, antioxidant properties and chemical composition of seaweeds collected from Saudi Arabia (Red Sea and Arabian Gulf). Saudi J. Biol. Sci. 24, 162-169 (2017).

[16] LESLIE, J. F. \& SUMMERELL, B. A. The Fusarium laboratory manual. (John Wiley \& Sons, 2008).

[17] DHINGRA, O. D. \& SINCLAIR, J. B. Location of Macrophomina phaseoli on soybean plants related to culture characteristics and virulence. Phytopathology 63, 934-936 (1973).

[18] CHOWDhurY, T. I., JUBAYER, M. F., UDDIN, M. B. \& AZIZ, M. G. Production and characterization of pectinase enzyme from rhizopus oryzae. Potravin. Slovak J. Food Sci. 11, 641651 (2017).

[19] BODET, C. A. 3RD, JORGENSEN, J. H. \& DRUTZ, D. J. Simplified bioassay method for measurement of flucytosine or ketoconazole. J. Clin. Microbiol. 22, 157-160 (1985).

[20] EL SHAFAY, S. M., ALI, S. S. \& EL-SHEEKH, M. M. Antimicrobial activity of some seaweeds species from Red sea, against multidrug resistant bacteria. Egypt. J. Aquat. Res. 42, 65-74 (2016).

[21] GOMEZ, K. A. \& GOMEZ, A. A. Statistical procedures for agricultural research. (John Wiley \& Sons, 1984).

[22] EL-SHEEKH, M. M. \& SOLIMAN, A. S. Biological control of Fusarium solani, Rhizoctonia solani and Macrophomina phaseolina infecting cucumber by some seaweeds culture Mostafa M. ElSheekh1, Amira Sh. Soliman2, Siham E. Abdel-Ghafour3, Hassan M. Sobhy2 and AY Ahmed3.

[23] ZOUAOUI, B. \& GHALEM, B. R. The Phenolic Contents and Antimicrobial Activities of Some Marine Algae from the Mediterranean Sea (Algeria). Russ. J. Mar. Biol. 43, 491-495 (2017).

[24] KHAN, S. A., ABID, M. \& HUSSAIN, F. Antifungal activity of aqueous and methanolic extracts of some seaweeds against common soil-borne plant pathogenic fungi. Pak. J. Bot 49, 1211-1216 (2017).

[25] AL-SAIF, S. S. A., ABDEL-RAOUF, N., EL-WAZANANI, H. A. \& AREF, I. A. Antibacterial substances from marine algae isolated from Jeddah coast of Red sea, Saudi Arabia. Saudi J. Biol. Sci. 21, 57-64 (2014).

[26] IBRAHEEM, B. M. I., HAMED, S. M., ABD ELRHMAN, A. A., FARAG, M. F. \& ABDELRAOUF, N. Antimicrobial activities of some brown macroalgae against some soil borne plant pathogens and in vivo management of Solanum melongena root diseases. Aust J Basic Appl Sci 11, 157-168 (2017).

[27] TIERNEY, M. S., CROFT, A. K. \& HAYES, M. A review of antihypertensive and antioxidant activities in macroalgae. Bot. Mar. 53, 387-408 (2010). 
[28] Celis, C., García, A., Sequeda, G., Mendez, G. \& Torrenegra, R. Antimicrobial activity of extracts obtained from anacardium excelsumagaints some pathogenic microorganisms. Emirates J. Food Agric. 249-257 (2011).

[29] JASIM, S. F., BAQER, N. N. \& ALRAHEEM, E. A. Detection of phytochemical constituent in flowers of Viola odorata by gas chromatography-mass spectrometry. Asian J. Pharm. Clin. Res. 11, 262 (2018).

[30] HUSEIN, A. I., ALI-ShTAYEH, M. S., JAMOUS, R. M., JONDI, W. J. \& ZATAR, N. A.-A. Phthalate derivatives are naturally occurring in Arum Palaestinum. Int J Curr Res Aca Rev 2, 195203 (2014). 